\title{
Potential health risks from the use of fibrous mineral absorption granulates
}

\author{
K RÖDELSPERGER, ${ }^{1}$ B BRÜCKEL,${ }^{1}$ J MANKE, ${ }^{1}$ H-J WOITOWITZ, ${ }^{1}$ F POTT $^{2}$
}

From the Institute and Policlinic for Occupational and Social Medicine of the Justus-Liebig-University of Giessen, ${ }^{1} 6300$ Giessen, and Medical Institute for Environmental Hygiene, ${ }^{2}$ University of Düsseldorf, 4000 Düsseldorf, Federal Republic of Germany

\begin{abstract}
Attapulgite (palygorskite) and sepiolite are fibrous clay minerals used commercially as components in a wide variety of products including oil and grease adsorbents, carriers for pharmaceuticals, cosmetics, and pesticides. They are also components of drilling muds and animal litter and they are used as paint thickeners. The current annual worldwide production of these minerals exceeds one million tons. Although fibrous in nature, the fibre length may vary greatly depending on the location of the geological deposits. American attapulgite is short $(0 \cdot 1-2.5 \mu \mathrm{m}$ in length, median of $0.4 \mu \mathrm{m})$ but palygorskite from other parts of the world is much longer (30\% longer than $5 \mu \mathrm{m})$. Several samples of these materials have been submitted to scanning transmission electron microscopy (STEM). This paper reports the results of microscopic evaluations and makes a comparison with the data from experimental carcinogenicity studies and it is concluded that fibre length is a most important carcinogenic property.
\end{abstract}

Attapulgite and sepiolite can occur in both long and short fibred varieties. Mesotheliomas were produced by intrapleural and intraperitoneal injections in animal experiments using the long attapulgite only. ${ }^{12}$ Extremely short fibrous varieties did not cause tumours after intraperitoneal or intrapleural injection (F Pott, unpublished data).

The analytical scanning transmission electron microscope (STEM) which can detect even very thin fibres was used to examine several samples of attapulgite and sepiolite. The materials were also compared with samples of erionite and crocidolite. In addition to determining fibre geometry the potential for contamination with asbestos fibres was also evaluated. Using the models of Stanton ${ }^{3}$ and Pott ${ }^{4}$ special attention was given to fibres longer than $5 \mu \mathrm{m}$ and thinner than $1 \mu \mathrm{m}$. Although only a small carcinogenic potential is assumed in the case of shorter fibres with a length between 2 and $5 \mu \mathrm{m}$, it has been hypothesised that this potential may increase if a large number of these fibres are present.

Accepted 21 July 1986

\section{Mineralogical description}

Of the materials used in industry, the clays attapulgite (palygorskite) and sepiolite (meerschaum) play a major part as adsorption granulates. Unlike the plate form clays, such as bentonite (montmorillonite) and kaolin, attapulgite and sepiolite develop needle like crystals (fig 1). Chemically, they are magnesium silicates with varying proportions of $\mathrm{Al}$ and $\mathrm{Fe}$. Apart from their length, their most significant property is their large effective surface; 130 to $310 \mathrm{~m}^{2} / \mathrm{g}$ for attapulgite and 150 to $250 \mathrm{~m}^{2} / \mathrm{g}$ for sepiolite. Depending on preliminary treatment, a distinction must be made between colloidal and calcined, thermally activated product types that have a different water solubility. ${ }^{6}$

\section{Production and use}

Bignon estimates the production of attapulgite and sepiolite in the western world to be at least $1.2 \mathrm{~m}$ tons a year. ${ }^{7}$ In the United States alone, about 900000 tons a year of attapulgite are mined. The remainder is produced in Spain, France, and Turkey.

The main uses for attapulgite and sepiolite are listed in table 1. Adsorption granulates constitute the majority of attapulgite and sepiolite products. In the 


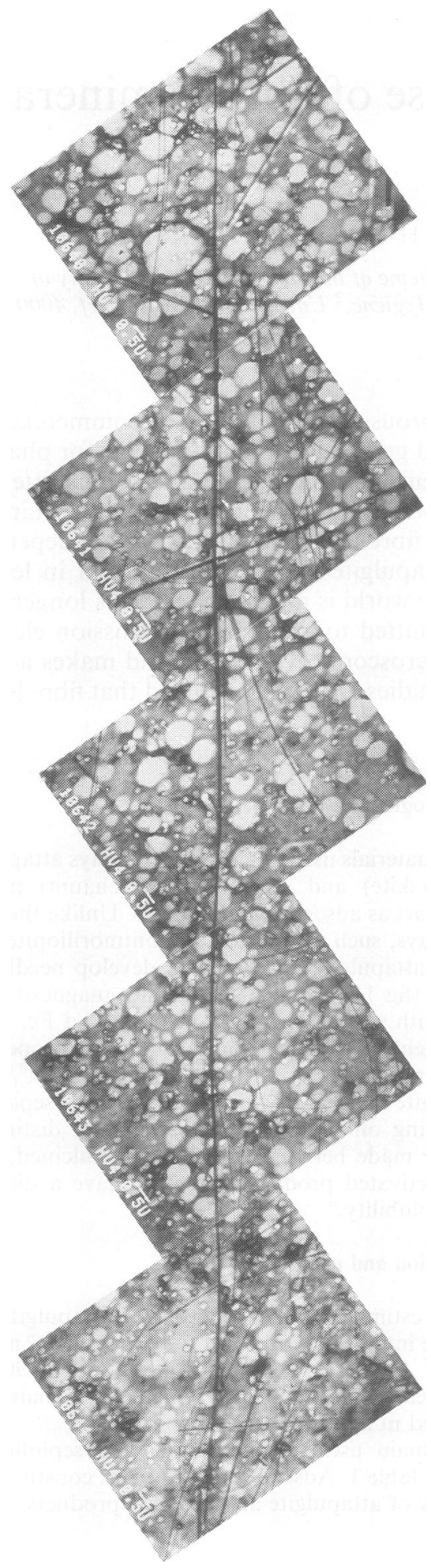

Table 1 Uses of attapulgite and sepiolite ${ }^{67}$

Thickener and thixotropic substances:

Paints, adhesives

Stabiliser in liquids:

Suspension fertiliser

Probe washing for oil drilling

Asbestos substitute:

Plaster filler, joint filler, underseal, sealants, brake linings

Sorption substances:

Old oil recycling, purification of hydrocarbons

Bases:

Pesticides

Catalysts

Liquid adsorption:

Oil, animal urine

Soil amelioration substances:

Horticulture in the United States

United States alone, where about 700000 tons a yearid of attapulgite are used, more than two thirds is found in oil and grease adsorbents, as carriers for pesticides,, and as pet litter.

By comparison, in the Federal Republic of Ger- $\overline{3}$ many the annual use of mineral adsorption granulates is estimated at more than one million tons. For ani- $\vec{\bullet}$ mal litter alone, an annual production quantity of 145000 tons a year mainly of sepiolite and attapulgite is reported (WLohrer, personal communicationo 1984).

\section{Biological effect}

Because of its fibrous nature, samples of attapulgite $\overrightarrow{\bar{O}}$ were used in earlier animal experiments by the 3 research teams of Stanton et $a l^{8}$ and Pott and Huth ${ }^{1}{ }_{F}$ investigating the relation between carcinogenicity and? fibre length. Although the intrapleural application of $40 \mathrm{mg}$ short fibrous United States attapulgite per rat 3 did not lead to an increased incidence of meso- -0 thelioma, mesotheliomas could be generated in $65 \%$. of rats after the intraperitoneal injection of $75 \mathrm{mg}$ of a long fibrous palygorskite. Additional positive findings have been obtained by Wagner ${ }^{2}$ with longo fibrous Spanish attapulgite from Torrejon. Some cell tests $^{7910}$ found a strong haemolytic and cytotoxico effect in the case of short fibrous attapulgite specimens. Using Stanton's precisely measured originalos dust samples, Lipkin showed no cytotoxic effect for N short fibrous United States attapulgite.$^{11} 12$ Addi-N్ల్ tional experiments carried out on organ cultures of 0 the hamster trachea, ${ }^{13}$ hamster alveolar cells, and human tumour cells ${ }^{9}$ also showed no in vitro effect of short fibred attapulgite.

Fig 1 Sepiolite fibre, length $33 \mu \mathrm{m}$ and diameter of $0.1 \mu \mathrm{m}$ in sample from a Finnish deposit. Much thinner fibres of diameters down to $0.01 \mathrm{\mu m}$ are also visible. 


\section{Materials and methodology}

\section{TEST SAMPLES}

We began our tests with four attapulgite samples from the United States (Georgia*), France (Mormoiront), Spain (Lebrija), and France (de Cacèrès).

These samples had been used in an injection experiment to investigate the potential to generate peritoneal mesotheliomas in rats; however, a carcinogenic effect could not be established for the first three of these materials but only for the last (F Pott, unpublished data). Sepiolite samples were also available from Spain (Uiacaluaro) and Finland. No commercial mining is done at the Finnish deposit (A Tossavainen and $\mathrm{K}$ Korhonen, 21st International Congress on Occupational Health, Dublin, September 1984).

For comparison, electron microscopic analyses were made with UICC crocidolite, a long fibrous Spanish attapulgite (Torrejon), and with erionite from Oregon. The latter two samples were provided by Dr Wagner who had shown an oncogenic potential in an intrapleural test. ${ }^{2}$

\section{SAMPLE PREPARATION}

Up to $5 \mathrm{mg}$ of the substance was made into a suspension in $50 \mathrm{ml}$ distilled water by a 30 minute ultrasonic treatment. After a dilution of 1:10, up to $20 \mathrm{ml}$

*Two samples of American attapulgite were available. One has been used in an injection experiment (F Pott, unpublished data) (Georgia 1 ), the other in an in vitro study ${ }^{10}$ (Georgia 2).

†This was actually a sample of a medicine used for gastric upsets, Gastropulgit.

Table 2 Fibre concentrations and median values of the fibre dimensions for different types of attapulgite and sepiolite compared with erionite from Oregon and with UICC crocidolite. The number of fibres of any length and the fibre dimensions are determined at a magnification of $29000 \times$ under the STEM operation mode. The analysis of the fibres $L \geqslant 5 \mu m$ is made mainly at a magnification of $10000 \times$ in the TEM operation mode. The attapulgite from Torrejon and the erionite and the crocidolite were given ultrasonic treatment for a short time only. of this suspension was filtered through Nucleporefilters (diameter $25 \mathrm{~mm}$, pore-size $0 \cdot 2 \mu \mathrm{m}$ ).

The filters for transmission electron microscopy were prepared by carbon coating and dissolving the filter material in a "Jaffewasher."

In the case of the attapulgite samples from Georgia, Mormoiron, and Lebrija three equal but independent preparations of each substance were analysed. Two preparations of the attapulgite from Torrejon, the erionite and the UICC crocidolite were analysed.

\section{ANALYSIS BY STEM}

Up to 431 fibres of any length per substance were counted under the STEM operation mode at a magnification of $29000 \times$ and their dimensions measured. Since the attapulgite and sepiolite samples are almost exclusively made up of extremely fine fibres of $<5 \mu$ m length, the measured surface amounted to only about $1 / 1000$ to $1 / 100 \mathrm{~mm}^{2}$. As a result, the sensitivity decreased to $10^{6}$ to $10^{8}$ fibres/mg per fibre found.

A separate count under the transmission electron microscope operation mode (TEM) with a far greater sensitivity at a magnification of $10000 \times$ was made to search for fibres with a length of $\geqslant 5 \mu \mathrm{m}$ and also for asbestos fibres. In doing this, $0.5 \mathrm{~mm}^{2}$ or 50 fields of the transmission preparation, which had been transferred on a 400 mesh copper grid, were examined. Each fibre $\mathrm{L} \geqslant 5 \mu \mathrm{m}$ was analysed using energy dispersive $x$ ray analysis and selected area electron diffraction.

\section{Results}

FIBRE CONCENTRATION MEASUREMENTS

Table 2 lists the calculated fibre concentrations based 
on both the STEM (all lengths) and TEM (lengths $\geqslant 5 \mu \mathrm{m}$ ) analyses and gives the median dimensions of fibres actually measured for all attapulgite and sepiolite specimens, as well as the Oregon erionite studied by Wagner and UICC crocidolite. The results of experimental carcinogenicity testing are also given. The American attapulgite, and the Spanish and Finnish sepiolite, showed the highest overall concentration of individual fibres when fibres of any length were examined $\left(10^{10}\right.$ to $10^{11}$ fibres $\left./ \mathrm{mg}\right)$. For the attapulgite, erionite, and crocidolite samples which had proved to be carcinogenic in animal experiments, the concentrations of fibres of any lengths were significantly lower $\left(10^{8}\right.$ to $10^{10}$ fibres $\left./ \mathrm{mg}\right)$. The concentrations of long fibres (lengths $\geqslant 5 \mu \mathrm{m}$ ) for these four carcinogenic fibre samples and for the two sepiolite samples amounted to 64 to $5500 \times 10^{6}$ fibres $/ \mathrm{mg}$. By contrast, as is seen in fig 2 and table 3 the non-carcinogenic attapulgite samples had few fibres longer than $5 \mu \mathrm{m}$. Between three and eight fibres longer than $5 \mu \mathrm{m}$ observed for these samples resulted in a fibre concentration calculated to be 0.06 to $0.6 \times 10^{6}$ fibres $/ \mathrm{mg}$ longer than $5 \mu \mathrm{m}$. Of these longer fibres, between 0 and 5 were found to be chrysotile, compared with one fibre of chrysotile observed on average in the filter and distilled water materials used in this study.

ANALYSIS OF FIBRE DIMENSIONS

The median values of the fibre dimensions measured

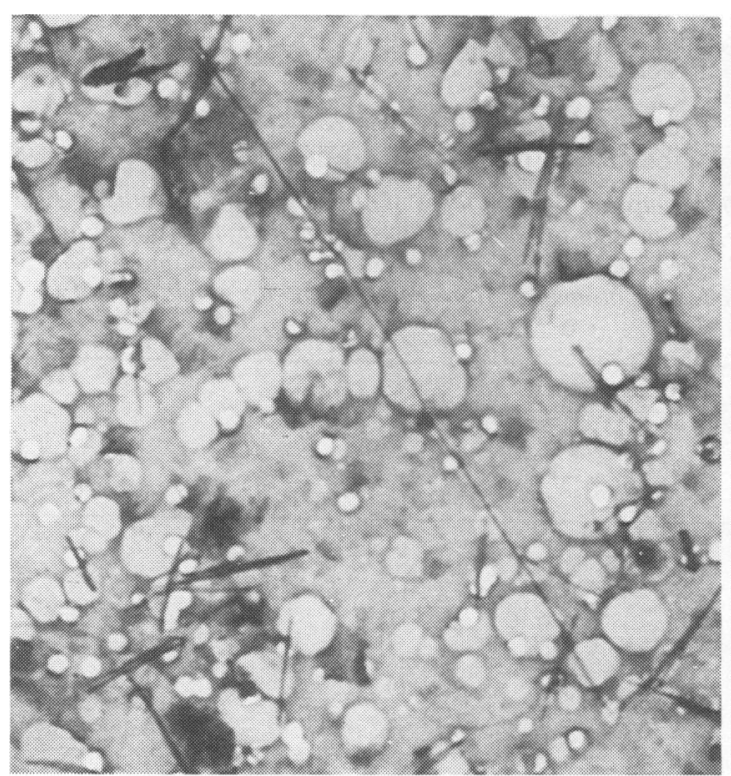

Rödelsperger, Brückel, Manke, Woitowitz, Poळ̄

at a magnification of $29000 \times$ are listed in table 2. Iब is remarkable that the erionite and crocidolite fibres. have a greater diameter than the attapulgite and sepi $\stackrel{\overrightarrow{\bar{F}}}{\vec{*}}$ olite. On the other hand, the attapulgite from Toro rejon and the erionite and sepiolite from Spain anf Finland are distinctly longer than the three shor fibrous attapulgite samples. Figure 3 gives a com $\vec{\oplus}$ parison of the three dimensional length and diamete distribution of four of the attapulgite samples and the four sepiolite, erionite, and crocidolite sampleș examined.

\section{Discussion}

EVALUATION OF THE METHOD

(1) Hand shaken suspensions of attapulgite an sepiolite samples contain both particle like fibre, flocks, which are not countable as fibres, and thickee clusters of fibres. It was easier partially to dispers@ these flocks and clusters into thin fibres with a diameter of $0.01 \mu \mathrm{m}$ for attapulgite than it was to dQ so with sepiolite using weak ultrasonic treatment. ${ }^{14}$ complete dispersion with the same result was accom $\overrightarrow{0}$ plished, this time using strong ultrasonic treatmento After an injection of hand shaken samples into rats, and subsequent analysis of the lung ash, very thiro fibres without any clusters were seen. ${ }^{14}$ Thus strons ultrasonic treatment is considered a suitable metho\$ of preparation. This does not apply to the attapulgite from Torrejon; as described above, it was treate\&

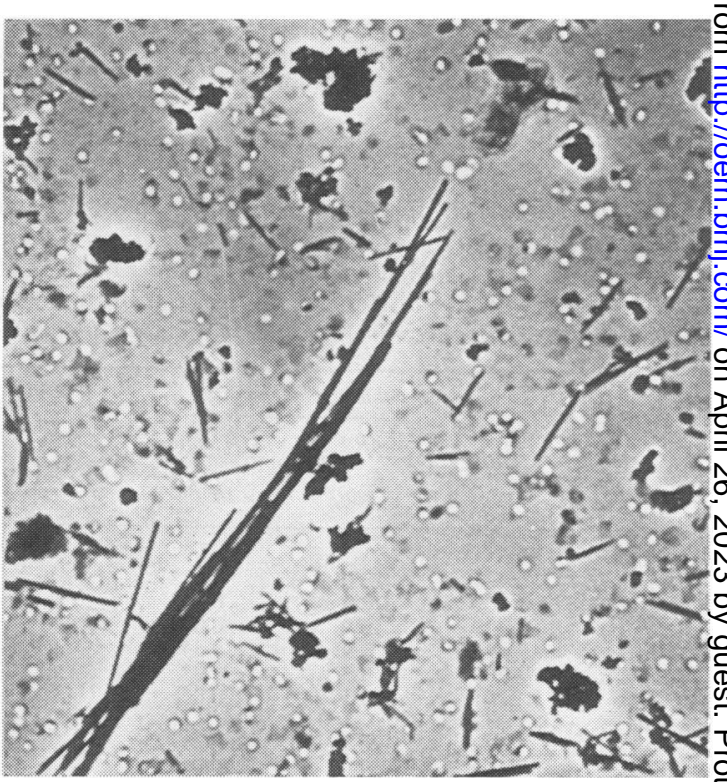

Fig 2 Fibres with $L \geqslant 5 \mu \mathrm{m}$ in short fibrous attapulgite samples. Left: Attapulgite fibre, length $6 \cdot 7 \mu \mathrm{m}$, in sample from Georgia. Photograph taken in STEM operation mode, magnification $15000 \times$. Right: Clusters of chrysotile fibres length $12 \mu \mathrm{m}$ in attapulgite sample from Mormoiron. Photograph taken in STEM operation mode, magnification $6300 \times$. 
Potential health risks from the use of fibrous mineral absorption granulates

Table 3 Concentration of the attapulgite and chrysotile fibres with $L \geqslant 5 \mu \mathrm{m}$ found in the attapulgite samples examined. All fibres were identified as attapulgite or chrysotile. (Upper limit of the $95 \%$ interval of reliability according to Poisson statistics in parentheses)

\begin{tabular}{|c|c|c|c|}
\hline & \multirow[b]{2}{*}{ No } & \multicolumn{2}{|c|}{ Fibre concentration $L \geqslant 5 \mu \mathrm{m}[\mathrm{F} / \mathrm{mg}] \times 10^{6}$} \\
\hline & & Attapulgite & Chrysotile \\
\hline $\begin{array}{l}\text { Georgia } 1 \\
\text { Georgia } 2 \\
\text { Mormoiron } \\
\text { Lebrija } \\
\text { Torrejon* } \\
\text { Cacèrès }\end{array}$ & $\begin{array}{r}3 \\
5 \\
8 \\
5 \\
102 \\
50\end{array}$ & 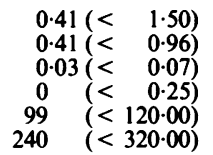 & $\begin{array}{l}0.20(<1.10) \\
0 \quad(<0.30) \\
0.03(<0.07) \\
0.34(<0.79) \\
\text { No analysis made } \\
\text { No analysis made }\end{array}$ \\
\hline
\end{tabular}

*Preparation with short term ultrasonic treatment.

ultrasonically for a short time and had completely dispersed into very fine fibres.

(2) No noteworthy deviations in the dimensions and concentrations of different preparations from any

\section{Attapulgite}
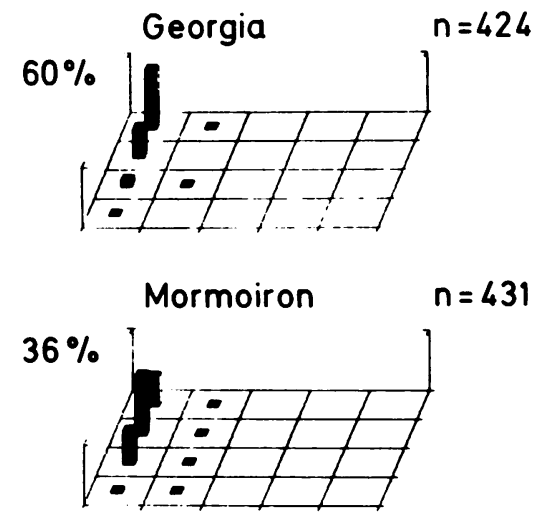

$n=431$

$36 \%$

Lebrija

$54 \%$

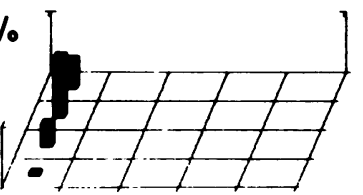

Torrejon

$$
n=200
$$

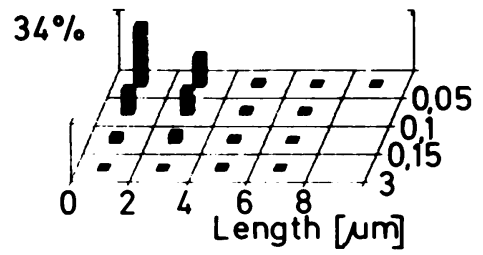

one mineral sample were observed, according to the Kolmogoroff-Smirnov test on the $95 \%$ level, and to the $95 \%$ confidence interval of the Poisson distribution.

Fig 3 Comparison of three dimensional length and diameter distribution of four attapulgite samples and four sepiolite, erionite, and crocidolite samples of different origin. Standardisation is made according to highest column which contains $19 \%$ to $60 \%$ of all fibres. 
The length and diameter distributions of short and long fibred attapulgite, sepiolite, and erionite samples examined here may also be compared with the individual results of measurements by other authors. $^{21415}$ This comparison shows a close conformity, especially relative to the order of magnitude of the difference between the short and long fibred samples. Nevertheless, the median length and width dimensions reported by Zumwalde for Georgian attapulgite, $0.4 \mu \mathrm{m}$ and $0.07 \mu \mathrm{m}$ respectively, were somewhat shorter than those reported here. ${ }^{15}$

(3) The comparisons of the different samples 1 and 2 from deposits in Georgia may be regarded as an example of the reproducibility of the concentration measurements. Fibre concentrations of all lengths differ by 29 and $72 \times 10^{9}$ fibres $/ \mathrm{mg}$, by the factor 2.4. The findings $\mathrm{L} \geqslant 5 \mu \mathrm{m}$ based on a smaller number of fibres are virtually identical. This difference-observed despite comparable fibre lengths and diameters-is caused by differing proportions of non-fibrous contamination. According to the data in table 2 , there is a close conformity between the attapulgite from Torrejon and a sample prepared by Hill and Griffith ${ }^{14}$ with intensive ultrasonic treatment.

In the sample of Hill and Griffith the concentration was $15.6 \times 10^{9} \mathrm{fibres} / \mathrm{mg}$ for all lengths and $85 \times 10^{6}$ fibres/mg $\mathrm{L} \geqslant 5 \mu \mathrm{m}$ by comparison with $9.6 \times 10^{9}$ and $99 \times 10^{6}$ fibres $/ \mathrm{mg}$ in the data shown in table 2 .

(4) From tables 2 and 3 it may be seen that the concentration of chrysotile and attapulgite fibres with a $\mathrm{L} \geqslant 5 \mu \mathrm{m}$-in the case of short fibred attapulgite samples-is at least lower a factor of 100 than the long fibred attapulgite and UICC crocidolite. It exceeds the asbestos fibre concentrations $\mathrm{L} \geqslant 5 \mu \mathrm{m}$ found in talc samples by at least a factor of 10 when similar analyses were conducted. ${ }^{16}$ However, up to five chrysotile fibres with a $\mathrm{L} \geqslant 5 \mu \mathrm{m}$ observed per 50 counting fields has to be considered to lie within the range of the detection limit determined by blind samples. This is calculated from the $95 \%$ confidence interval of Poisson statistics. For two fibres found per 100 counting fields, 3.6 fibres per 50 counting fields are estimated. Therefore, the observance of three or five fibres longer than $5 \mu \mathrm{m}$ for the attapulgite samples is not statistically significant.

BIOLOGICAL ASSESSMENT

Of the five attapulgite samples examined, four were definitely of the short fibrous type, whereas one sample (Torrejon) proved to be distinctly longer and was thus similar to the two sepiolite samples, the erionite and the crocidolite (see table 1). If one compares the distribution of the fibre dimensions with the carcinogenic effect of these dusts in most cases it will be found that the short fibrous dusts have not proved as carcinogenic as the long fibrous ones. The Spanis sepiolite is one exception because, on the one hand if is a relatively long fibrous type and on the other it difis not induce tumours. ${ }^{2}$ The two explanations for this are (1) the sample of sepiolite used by Wagner's carf cinogenicity test differed essentially from the sample which we examined, although the origin-so far a⿸ could be verified-was the same and (2) although the Spanish sepiolite has a larger proportion of longep fibres, so that carcinogenic effect is to be expected ${ }^{3}+4$ its firmness may be too low for the existing carcino genic agent to take effect.

Obviously specimens classified as attapulgite from a mineralogical viewpoint may differ greatly wits

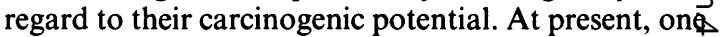
cannot judge whether only fibre length, which proveof to be greater in the carcinogenic samples, ${ }^{12}$ is decisive or whether a lower firmness was also important fow the lack of a carcinogenic effect in the short fibroug samples. ${ }^{5}$

The surveys on carcinogenicity available to date were made using extremely sensitive tests-either the intrapleural test ${ }^{2}$ or the intraperitoneal (F Pott $\vec{c}$ unpublished data) in the rat. An important questiono "To what extent are the samples examined represen:tative of the entire deposit?" is difficult to answer.

Furthermore, it is important to note that the negas tive result from the carcinogenicity test wit/o attapulgite (sample Georgia 1) (F Pott, unpublishe疋 data) cannot be predicted from the strong cyto@ toxicity and the haemolytic activity that was found in $\overrightarrow{5}$ vitro in the case of an attapulgite sample of a simila type (sample Georgia 2) ${ }^{10}$ The attapulgite samples "Georgia 1" and "Georgia 2" are virtually identicap. in the distributions of fibre dimensions (table 2) anके in their infrared spectra. The different reactions in $\$$ carcinogenicity test, by comparison with an in vitro test, show that positive findings from short term test오. may be misinterpreted with respect to carcinogeni 8 potential. Carcinogenicity tests with fibrous dusts on laboratory animals cannot, as yet, be replaced by iro vitro tests. Based on their findings, Wagner et al hav? warned against drawing conclusions from in vitro tests without taking in vivo mechanisms also int consideration. ${ }^{17}$

Our special thanks to Dr Wagner, Dr Tossavainetr and Dr Dunnigan for providing samples and to Dunnigan for making the infrared spectra of bot attapulgite samples from Georgia.

Supported by the German Federal Ministry for Sci ence and Technology, Bonn, Project-No 01 VD $2900^{\circ}$ 


\section{References}

1 Pott F, Huth F, Friedrichs KH. Tumorigenic effect of fibrous dusts in experimental animals. Environ Health Perspect 1974; 9:313-5.

2 Wagner JC. Health hazards of substitutes. In: Proceedings of the world symposium on asbestos, Montreal, 24-27 May 1982. Montreal: Canadian Asbestos Information Centre, 1982:244-66.

3 Stanton MF, Layard M. The carcinogenicity of fibrous minerals. In: Workshop on asbestos: definitions and measurement methods. 1978:143-51. (National Bureau of Standards spec publ 506.)

4 Pott F. Some aspects on the dosimetry of the carcinogenic potency of asbestos and other fibrous dust. Staub-Reinhaltung der Luft 1978;38:486-90.

5 Förster H, Burchard W-G. Kleintierstreu mineralogisch betrachtet. Fortschritte der Mineralogie 1984;62:57-8.

6 Nobel D. Attapulgit-Eigenschaften und Anwendung. Bremen: Sonderdruck der Chemie Mineralien KG, 1981.

7 Bignon J, Sebastien P, Gaudichet A, Jaurand MC. Biological effects of attapulgite. In: Wagner JC, ed. Biological effects of mineral fibres. Vol 2. Lyon: International Agency for Research on Cancer. 1980:163-82. (IARC sci publ No 30.)

8 Stanton MF, Layard M, Tegevis A, et al. Relation of particle dimension to carcinogenicity in amphibole asbestos and other fibrous minerals. J Natl Canc Inst 1981;67:956-75.

9 Chamberlain M, Davies R, Brown RC, Griffiths M. In vitro tests for the pathogenicity of mineral dusts. Ann Occup Hyg
1982;26:583-92.

10 Harvey G, Page M, Dumas L. Binding of environmental carcinogens to asbestos and mineral fibres. $\mathrm{Br} J$ Ind Med 1984; 41:396-400.

11 Lipkin LE. Cellular effects of asbestos and other fibers: correlations with in vivo induction of pleural sarcoma. Environ Health Perspect 1980;34:91-102.

12 Lipkin LE. Failure of attapulgite to produce tumours: prediction of this result by in vitro cytotoxicity test. In: Beck EG, Bignon $\mathrm{J}$, eds. In vitro effects of mineral dusts. Berlin: Springer-Verlag, 1985:539-42.

13 Woodworth CD, Mossman BT, Craighead JE. Induction of squamous metaplasia in organ cultures of hamster trachea by naturally occurring and synthetic fibers. Cancer Res 1983;43:4906-12.

14 Griffiths DM, Hill RJ. The effects of dispersion of fibrous clays in vitro and in vivo. Ann Occup Hyg 1983;27:405-14.

15 Zumwalde R. Industrial hygiene study of the Engelhard Minerals \& Chemicals Corporation. Cincinnati: National Institute for Occupational Safety and Health, 1977.

16 Rödelsperger K, Lojewski H-G, Brückel B, Woitowitz H-J. Zum Fasergehalt von Pudern auf Talkumgrundlage. StaubReinhaltung der Luft 1984:44:62-6.

17 Wagner JC, Griffiths DM, Hill RJ. The effect of fibre size on the in vivo activity of UICC-crocidolite. Br J Cancer 1984; 49:453-8.

\section{Vancouver style}

All manuscripts submitted to the $\mathrm{Br} J$ Ind Med should conform to the uniform requirements for manuscripts submitted to biomedical journals (known as the Vancouver style)

The $\mathrm{Br} J$ Ind Med, together with many other international biomedical journals, has agreed to accept articles prepared in accordance with the Vancouver style. The style (described in full in $\mathrm{Br}$ Med J, 24 February 1979, p 532) is intended to standardise requirements for authors.

References should be numbered consecutively in the order in which they are first mentioned in the text by Arabic numerals above the line on each occasion the reference is cited (Manson ${ }^{1}$ confirmed other reports ${ }^{2-5} \ldots$.). In future references to papers submitted to the $\mathrm{Br} J$ Ind Med should include: the names of all authors if there are six or less or, if there are more, the first three followed by et al; the title of journal articles or book chapters; the titles of journals abbreviated according to the style of Index Medicus; and the first and final page numbers of the article or chapter.

Examples of common forms of references are:

1 International Steering Committee of Medical Editors. Uniform requirements for manuscripts submitted to biomedical journals. Br Med J 1979;1:532-5.

2 Soter NA, Wasserman SI, Austen KF. Cold urticaria: release into the circulation of histamine and eosino-phil chemotactic factor of anaphylaxis during cold challenge. $N$ Engl $J$ Med 1976;294:687-90.

3 Weinstein L, Swartz MN. Pathogenic properties of invading micro-organisms. In: Sodeman WA Jr, Sodeman WA, eds. Pathologic physiology: mechanisms of disease. Philadelphia: W B Saunders, 1974:457-72. 